KS. JERZY ADAMCZYK

Wyższe Seminarium Duchowne w Radomiu

\title{
DEKANAT I URZĘDY DEKANALNE
}

Treść: Wprowadzenie. - 1. Nazwy, definicja i erekcja dekanatu. - 2. Zadania dekanatu. - 3. Urzędy dekanalne. - Wnioski.

\section{Wprowadzenie}

Dekret Soboru Watykańskiego II o pasterskich zadaniach biskupów w Kościele Christus Dominus stwierdza, że „bliższymi współpracownikami biskupa są również ci kapłani, którym powierza on misję duszpasterską lub dzieła apostolstwa o charakterze ponadparafialnym"1. W przywołanym zapisie soborowym nie wskazano wprawdzie imiennie żadnego stanowiska o charakterze ponadparafialnym, ale z łatwością dostrzega się tu nawiązanie do urzędu dziekana, który łączy się ściśle ze sprawą podziału terytorialnego diecezji na dekanaty, czyli wikariaty rejonowe (okręgowe, archiprezbiteriaty lub inaczej) $)^{2}$.

\footnotetext{
${ }^{1}$ Concilium Oecumenicum Vaticanum II, Decretum de pastorali Episcoporum munere in Ecclesia Christus Dominus [28 octobris 1965], nr 29, AAS 58(1966), s. 673-701, tekst polski: Soвór WATYкAŃski II, Dekret o pasterskich zadaniach biskupów w Kościele Christus Dominus, w: Sobór Watykański II. Konstytucje, dekrety, deklaracje. Tekst polski. Nowe tłumaczenie, Wydawnictwo Pallottinum, Poznań 2002, s. 236-258, (odtąd: CD).

${ }^{2}$ Codex Iuris Canonici. Auctoritate Ioannis Pauli PP. II promulgatus. Kodeks Prawa Kanonicznego, przekład polski zatwierdzony przez Konferencję Episkopatu, Wydawnictwo Pallottinum, Poznań 1984, (odtąd: KPK), kan. $553 \$ 1$.
} 
Kodyfikacja z 1983 r., przejmując w zasadzie instytucje dekanatów i dziekanów ${ }^{3}$, nie zobowiązała jednak biskupa diecezjalnego do podziału diecezji na dekanaty ${ }^{4}$, pozostawiając mu tym samym swobodę wyboru innych rozwiązań, które wyraźnie proponują różne dokumenty apostolskie okresu posoborowego ${ }^{5}$. Jednakże zarówno prawo partykularne, jak i praktyka duszpasterska dość powszechnie podtrzymują podział diecezji na dekanaty, w celu łatwiejszego sprawowania opieki duszpasterskiej poprzez wspólne działanie kilka sąsiednich parafii ${ }^{6}$.

Rodzi się zatem pytanie: skoro Kodeks i prawo partykularne przewidują instytucję dekanatu, to czym jest dekanat, jakie są jego zadania, czy cała odpowiedzialność za funkcjonowanie dekanatu winna spoczywać wyłącznie na dziekanie, czy też można, w ramach prawa partykularnego, ustanowić inne urzędy, w celu owocniejszego wypełniania przez dekanat swojej funkcji? Jeśli tak, to jakie rozwiązania przyjmują poszczególni prawodawcy? Zasygnalizowanym problemom zostanie poświęcony niniejszy artykuł.

\section{Nazwy, definicja i erekcja dekanatu}

Gdy idzie o terminologię, to należy stwierdzić, że jest ona ściśle związania z nazwą urzędu kierującego dekanatem7, którego Kodeks

\footnotetext{
${ }^{3}$ Por. kan. 553-555, $374 \$ 2$.
}

${ }^{4}$ Kan. $374 \$ 2$.

${ }^{5}$ E. Sztafrowski, Ponadparafialni współpracownicy biskupa diecezjalnego, Prawo Kanoniczne 35(1992) nr 3-4, s. 25.

${ }^{6}$ Congregaticio pro Episcopis, Direttorio per il ministero pastorale dei vescovi „Apostolorum Successores” [22 febbraio 2004], nr 218, Città del Vaticano 2004, tekst polski: Kongregacja Do spraw BIsKupów, Dyrektorium o pasterskiej posłudze biskupów „Apostolorum Successores”, Wydawnictwo Jedność, Kielce 2005, (odtąd: AS); por. Z. Książek, Rola urzędu dziekańskiego w pasterskiej posłudze biskupa według Kodeksu Jana Pawła II, Analecta Cracoviensia 41(2009), s. 484-485.

7 Trzeba zauważyć, że w porównaniu z poprzednim Kodeksem w nowym Kodeksie wikariat zewnętrzny stracił nieco z doniosłości instytucjonalnej. W zakresie terminologii aktualny Kodeks posiada tylko nazwę vicariatus, gdy tymczasem wielość nazw odnosi się wyłącznie do tego, kto rządzi wikariatem zewnętrznym, który oprócz wikariusza zewnętrznego, może być nazywany dziekanem, archiprezbiterem 
Prawa Kanonicznego z 1983 r. nazywa wikariuszem rejonowym, zwanym także dziekanem albo archiprezbiterem, albo jeszcze inaczej. Prawodawca podkreśla, że ów prezbiter stoi na czele wikariatu rejonowego. Tak więc według KPK dekanat ${ }^{8}$ nazywany jest wikariatem rejonowym $^{9}$, wikariatem ${ }^{10}$, okręgiem ${ }^{11}$, rejonem ${ }^{12} \operatorname{archiprezbiteratem~}^{13}$, wikariatem zewnętrznym ${ }^{14}$.

Co się tyczy definicji dekanatu ${ }^{15}$, to prawodawstwo powszechne nie podaje takowej. Jednak na podstawie materiału prawnego zawartego w KPK można skonstatować, że dekanat jest to specjalny zespół kilku połączonych sąsiednich parafii (jednostka administracyjna), celem wsparcia pasterzowania przez wspólne działanie, na którego czele stoi wikariusz rejonowy, będący kapłanem, zwany także

albo jeszcze inaczej. Nie wydaje się jednak, aby autorzy KPK zamierzali ujednolicić terminologię odnośnie do instytucji wikariusza zewnętrznego. Por. G. MontinI, I vicari foranei, Quaderni di Diritto Ecclesiale 4(1991) z. 3, s. 381.

${ }^{8}$ Kan. $553 \$ 1$. warto przypomnieć, że łacińska wersja KPK nie używa nazwy dekanat, lecz wikariat zewnętrzny (vicariatus foraneus), lub wikariat (vicariatus), okręg czy rejon (districtus). Kan. 553-555, $374 \$ 2$. Districtus oznacza także obszar, okolicę, obwód, powiat. A. Jougan, Słownik kościelny łacińsko-polski, Wydawnictwo Archidiecezji Warszawskiej, Warszawa 1992, s. 206. Polska edycja KPK używa także słowa dekanat, co nie ma potwierdzenia w tekście łacińskim. Por. SACRA CongreGATIO PRo Episcopis, Directorium Ecclesiae imago de pastorali ministerio Episcoporum [22 februarii 1973], nr 184-187, w: Enchiridion Vaticanum, t. 4, Bologna 1997 nr 1945-2328, tekst polski: KongregaCja Biskupów, Instrukcja Ecclesiae imago na temat pasterskiej posługi biskupów, w: E. Sztafrowski, Posoborowe Prawodawstwo Kościelne, t. 6, z. 1, nr 10370-11035, (odtąd: EI).

${ }^{9}$ Kan. $374 \S 2,553 \$ 1$, AS, nr 218.

${ }^{10} \mathrm{Kan} .553 \S 2.555 \S 1, \mathrm{nr} 1,555 \S 2$.

${ }^{11} \mathrm{Kan} .555 \$ 1, \mathrm{nr} 2,555 \$ 2$, nr 2.

${ }^{12}$ Kan. $555 \$ 3-4$.

${ }^{13} \mathrm{EI}, \mathrm{nr} 186, \mathrm{AS}, \mathrm{nr} 218$, por. kan. $553 \S 1$.

${ }^{14} \mathrm{EI}, \mathrm{nr} 186$.

${ }^{15}$ Polskie słowo „dziekan”, a zwłaszcza „dekanat” wywodzi się z języka łacińskiego, od decem, wcześniej z greckiego „deka”, oznaczającego liczbę dziesięć. Por. E. Sztafrowski, Ponadparafialni wspótpracownicy, s. 30-31. Dekanaty istnieją w Kościele już od IV wieku. J. Llaquet, Arciprestazgo, w: Diccionario General de Derecho Canónico, Obra dirigida y coordinada por J. Otaduy, A.Viana, J. Sedano, vol. I, Editorial Aranzadi, Pamplona 2012, s. 462. 
dziekanem albo archiprezbiterem, albo jeszcze inaczej ${ }^{16}$. Definicję opisową dekanatu podaje niekiedy prawo partykularne. Np. Statut księży dziekanów Archidiecezji Częstochowskiej stwierdza, że zgodnie $\mathrm{z}$ wielowiekową tradycją, potwierdzoną $\mathrm{w}$ prawie powszechnym i partykularnym, parafie sąsiadujące ze sobą są łączone w liczbie około dziesięciu w okręgi, czyli jednostki organizacji terytorialnej diecezji, nazywane dekanatami. Przewodzi takiemu okręgowi kapłan znany pod nazwą dziekana. Jest on pośrednikiem między Arcybiskupem Częstochowskim i Kurią Metropolitalną a duchowieństwem i wiernymi świeckimi dekanatu w określonych sprawach ${ }^{17}$. Wytyczne dla pracy dekanatu i urzędów dekanalnych Archidiecezji Krakowskiej podkreślają, że dekanat jest ogniwem pośrednim między biskupem diecezjalnym i kurią, a parafiami Kościoła Krakowskiego choć sam, jako struktura, nie jest samodzielnym podmiotem życia kościelnego ${ }^{18}$. Statuti degli organi di partecipazione diocesani diecezji Concordia-Pordenone przyjmują, że dekanat tworzy zgrupowanie kilka sąsiednich parafii, wewnątrz Kościoła partykularnego, w celu popierania wzrostu duchowego tych wspólnot parafialnych, dawania odpowiedzi

\footnotetext{
${ }^{16}$ Por. kan. $374 \$ 2,553 \$ 1$. Dekanat lub wikariat rejonowy albo archiprezbiterat, jest to specjalny zespół kilku połączonych sąsiednich parafii, w celu łatwiejszego sprawowania opieki duszpasterskiej poprzez wspólne działanie. Por. AS, nr 218. Zob. M. Sitarz, Słownik prawa kanonicznego, Warszawa 2004, k. 38; por. T. PAwLuk, Dekanat, w: Encyklopedia Katolicka, pod red. R. Łukaszyka, t. 3, Lublin 1995, k. 1114; por. J. Ostrowski, Dekanat, w: Leksykon teologii pastoralnej, pod red. R. Kamińskiego, W. Przygody, M. Fiałkowskiego, Lublin 2006, s. 161. „KPK rozumie dekanat jako fakultatywną grupę ustanowioną przez tego, kto stoi na czele diecezji lub innego Kościoła partykularnego, który, aby ułatwić opiekę duszpasterską w różnych parafiach leżących blisko siebie, może połączyć je w szczególne grupy zwane dekanatami”. J. Llaquet, Arciprestazgo, s. 462.

17 Arcybiskup Metropolita CzęStochowski, Statut księży dziekanów Archidiecezji Częstochowskiej, http://kuriaczestochowa.pl/wp-content/uploads/2013/02/14. pdf, [dostęp: 15.11.2015], I, 1; por. Statut Księży Dziekanów Archidiecezji Lubelskiej [2 grudnia 2000], I, 1, Wiadomości Archidiecezji Lubelskiej 74(2000) nr 4, s. 713.

${ }^{18}$ Wytyczne dla pracy dekanatu i urzędów dekanalnych Archidiecezji Krakowskiej [3 czerwca 1992], art. 1, Notificationes e Curia Metropolitana Cracoviensi 130(1992) nr 7-9, s. 58.
} 
na potrzeby duszpasterskie wiernych i wyrażania zdecydowanego zaangażowania misyjnego, jakie jest wymagane w trzecim tysiącleciu ery chrześcijańskiej ${ }^{19}$. Natomiast Statut für die Dekanate diecezji mogunckiej przypomina, że dekanat obejmuje kilka parafii zgodnie $\mathrm{z}$ aktualnym planem strukturalnym diecezji Moguncja ${ }^{20}$. Z kolei Sinodo $47^{\circ}$ della Chiesa ambrosiana stanowi, że dekanat to struktura terytorialna diecezji, która obejmuje pewną liczbę sąsiednich parafii leżących blisko siebie, a czasami wzajemnie połączonych w unità pastorali, w celu wspierania opieki duszpasterskiej poprzez wspólne działania ${ }^{21}$.

Odnośnie do erecji dekanatów kan. $374 \$ 2$ postanawia: „celem wsparcia pasterzowania przez wspólne działanie, kilka sąsiednich parafii może być łączonych w specjalne zespoły, jakimi są wikariaty okręgowe"22. Znaczy to, że według obecnie obowiązującej dyscypliny biskup diecezjalny nie ma obowiązku (który nakładał poprzedni Kodeks ${ }^{23}$ ) dzielić diecezji na dekanaty. Tworzenie dekanatów wskazuje się

19 Diocesi di Concordia-Pordenone, Statuti degli organi di partecipazione diocesani, Pordenone 2006, art. 1, s. 21.

${ }^{20}$ Bistum Mainz, Statut für die Dekanate, www.bistummainz.de, [dostęp: 21.01.2016], $\$ 1$, nr 1, s, 1 .

${ }^{21}$ Sinodo $47^{\circ}$ della Chiesa ambrosiana, Edizioni Centro Ambrosiano, Milano 1995, st. $161 \S 1$, s. 57 .

${ }^{22}$ Odnośnie do erekcji dekanatu i mianowania dziekana trzeba zauważyć, że obydwie te kwestie, które niewątpliwie łączą się ze sobą, są zamieszczone w Kodeksie w dwóch mocno oddzielonych od siebie miejscach. Na temat ustanawiania dekanatów jest mowa w związku z Kościołami partykularnymi, a ściślej mówiąc w rozdziale I (a więc niejako wstępnym) tytułu I sekcji II (Kościoły partykularne oraz ich zespoły), który zawiera następujący materiał prawny: „Kościoły partykularne i ustanowiona w nich władza”. Wspomniany rozdział I jest zatytułowany „Kościoły partykularne" (kan. 368-374) i zawiera ogólne sprawy, czy raczej sformułowania dotyczące tych Kościołów. Natomiast sprawa dotycząca samych dziekanów jest umieszczona, zgodnie z projektami Komisji Odnowy KPK, dopiero po proboszczach (kan. 553-555), gdzie na pierwszym miejscu jest mowa o ich ustanawianiu. Wydaje się, że taki układ materii prawnej, różny od systematyki poprzedniego Kodeksu nie jest zbyt trafny. Por. E. SzTafrowski, Ponadparafialni współpracownicy, s. 40-41.

${ }^{23}$ Kodeks z 1917 r. regulację instytucji dekanatu umieścił wśród kanonów odnoszących się do duchowieństwa w szczególności, zobowiązując biskupa - z wyjątkiem 
tutaj jako jedną z możliwości. Biskup może wybrać inne rozwiązania, uwzględniając dobro duchowe własnej diecezji ${ }^{24}$. Instrukcja Ecclesiae imago zawiera zapis: „biskup uważa za bardzo pożyteczne ustanowienie tych okręgów administracyjnych (dekanatów terytorialnych, czy personalnych), jak również ich prawidłową i skuteczną działalność, ponieważ przyczyniają się w znacznym stopniu do zespolonej działalności duszpasterskiej i stanowią konieczne środki do realizowania zasady pomocniczości i właściwie uporządkowanego posługiwania w diecezji" 25 .

Trzeba dodać, że biskup diecezjalny nie tylko ma prawo erygować dekanaty, ale znosić je, czy dokonywać w nich zmian ${ }^{26}$. Przykładowo Statut księży dziekanów Archidiecezji Lubelskiej postanawia, że dekanat eryguje i dokonuje w nim zmian arcybiskup lubelski, po konsultacji z radą kapłańską oraz zainteresowanymi dziekanami i proboszczami ${ }^{27}$. Natomiast Sinodo $47^{\circ}$ della Chiesa ambrosiana

niemożności ze względu na okoliczności, albo słuszną przyczynę i po uprzedniej konsultacji ze Stolicą Apostolską - podzielić swoje terytorium na rejony lub okręgi złożone z różnych parafii, nazywane wikariatami zewnętrznymi, dekanatami albo archiprezbiteratami. Codex Iuris Canonici, Pii X Pontificis Maximi iussu digestus, Benedicti, Papae XV auctoritate promulgatus, Typis Polyglottis Vaticanis, Romae 1951, kan. 217. Por. J. Llaquet, Arciprestazgo, s. 462. Zob. A. Bressani, La chiesa particolare, w: Il diritto nel mistero della Chiesa. Il popolo di Dio e la sua struttura organica, pod red. Gruppo Italiano Docenti di Diritto Canonico, vol. 2, Roma 1981, s. 400.

${ }^{24}$ Por. E. Sztafrowski, Ponadparafialni wspótpracownicy, s. 37. 2. „Dekanat eryguje (...) Arcybiskup Lubelski, po konsultacji z Radą Kapłańską oraz zainteresowanymi dziekanami i proboszczami”. Statut Księży Dziekanów Archidiecezji Lubelskiej, art. I, nr 2, s. 713; por. G. Montini, I vicari foranei, s. 382.

${ }^{25}$ EI, nr 184; Możliwość i pożytek z tworzenia dekanatów i tym podobnych struktur administracyjnych podkreśla AS, nr 218; por. J. Osтrowsкi, Dekanat, s. 162.

${ }^{26}$ Warto zauważyć, że w obecnej sytuacji prawnej biskup diecezjalny mógłby wprawdzie znieść w swojej diecezji instytucję dekanatu, lecz mógłby postawić się wtedy w trudnej sytuacji, gdyby w jego diecezji istniał niepamiętny, a więc prawomocny zwyczaj podziału na dekanaty. Por. G. Montini, I vicari foranei, s. 382.

${ }^{27}$ Statut Księży Dziekanów Archidiecezji Lubelskiej, art. I, nr 2, s. 713. „Dekanat eryguje i dokonuje w nim zmian arcybiskup częstochowski, po konsultacji z Radą Kapłańską oraz zainteresowanymi dziekanami i proboszczami”. ARCYBiskuP 
stwierdza, że aktualny podział archidiecezji na dekanaty musi być ponownie starannie zbadany i w razie potrzeby zmieniony w tym celu, aby każdy dekanat był w stanie realizować w lepszy sposób własne funkcje $\mathrm{e}^{28}$.

Dyrektorium Ecclesiae imago podaje ponadto kryteria tworzenia dekanatów. Stąd przy erygowaniu dekanatów biskup winien mieć na uwadze następujące racje: obyczaje wiernych, charakter psychiczny i jednakowe warunki społeczne; te same lub podobne warunki geograficzne i historyczne; te same potrzeby ekonomiczne i administracyjne, jak również wspólne obyczaje i karność (np. ta sama kopalnia, ten sam okręg fabryczny, jakiś nizinny teren); żeby prezbiterzy między sobą i z dziekanem mogli się często spotykać; długotrwałe tradycje ${ }^{29}$.

Natomiast Dyrektorium o pasterskiej posłudze biskupów „Apostolorum Successores” postanawia, że po to, aby umożliwić realizację ich celów duszpasterskich w erygowaniu dekanatów lub podobnych struktur, biskup powinien uwzględniać następujące kryteria: jednorodność pod względem charakteru i zwyczajów danej populacji, wspólna charakterystyka danego obszaru geograficznego (np. jakaś dzielnica miejska, okręg górniczy, jakiś rejon), bliskość parafii pod względem geograficznym i historycznym, łatwość przeprowadzenia okresowych spotkań dla duchowieństwa oraz inne, nie pomijając oczywiście zwyczajów związanych z tradycją ${ }^{30}$.

\section{Zadania dekanatu}

W kan. $374 \$ 2$ podkreśla się, że kilka sąsiednich parafii może być łączonych w specjalne zespoły, jakimi są wikariaty rejonowe (dekanaty) „celem wsparcia pasterzowania przez wspólne działanie”31. Dyrektorium Ecclesiae imago podkreśla, że instytucja dziekaństwa

Metropolita Częstochowski, Statut księży dziekanów Archidiecezji Częstochowskiej, art. I, nr 2.

${ }^{28}$ Sinodo $47^{\circ}$ della Chiesa ambrosiana, st. 162, s. 57.

${ }^{29} \mathrm{EI}, \mathrm{nr}$ 185; por. J. Ostrowski, Dekanat, s. 162.

${ }^{30}$ AS, nr 218. Zob. G. Montini, I vicari foranei, s. 377.

${ }^{31}$ Por. J. Dyduch, Posoborowe ujęcie funkcji dziekana, Notificationes 120(1982) nr 12, s. 286-287; G. Montini, I vicari foranei, s. 376. 
ma na uwadze to, żeby przy pomocy dziekana proboszczowie lub pracownicy duszpasterstwa tego samego terytorium albo tej samej dziedziny społecznej stworzyli jakby jakąś żywą komórką diecezjalnego prezbiterium. W jej ramach ma się dokonywać koordynacja specyficznego apostolstwa również zakonników, zakonnic i świeckich, pracujących na tym samym terytorium lub w tym samym resorcie. W ten sposób wspólna działalność duszpasterska będzie właściwie rozwijana i kierowana ${ }^{32}$. Z kolei instrukcja O pasterskiej posłudze biskupów „Apostolorum Successores” akcentuje, że w celu łatwiejszego sprawowania opieki duszpasterskiej poprzez wspólne działanie kilka sąsiednich parafii może zostać połączonych w specjalne zespoły, jakimi są wikariaty rejonowe nazywane także dekanatami albo archiprezbiteratami lub inaczej ${ }^{33}$.

Prawodawcy partykularni w swoich uregulowaniach niejednokrotnie dokładniej formalizują zdania dekanatu ${ }^{34}$. Np. Estatutos de los arciprestazgos de la Archidiócesis de Madrid stwierdzają, że dekanat posiada zadania ogólne i szczegółowe. Gdy chodzi o pierwsze to zadaniem dekanatu jest być narzędziem dialogu i skutecznym znakiem komunii diecezjalnej zarówno między parafiami połączonymi w archiprezbiterat, oraz między nimi a diecezjalnymi organami władzy rządzenia w tym, co dotyczy duszpasterstwa i administracji, które są wspólne dla wszystkich parafii dekanatu, w poszanowaniu autonomii i własnej kompetencji proboszczów zgodnie z prawomocnym prawem; następnie popieranie, koordynowanie i ułatwianie wspólnego duszpasterstwa, zgodnie z diecezjalnym planem duszpasterskim, biorąc pod uwagę swoiste cechy charakterystyczne każdego archiprezbiteratu; ofiarowanie parafiom i ich instytucjom tych dóbr i posług, które każdy z nich może zaoferować pozostałym, podsycając ducha misyjnego i dokonując odpowiednich wspólnych działań;

\footnotetext{
${ }^{32}$ EI, nr 185.

${ }^{33}$ AS, nr 218.

${ }^{34}$ Wspólne statuty dla dekanatów różnych Kościołów partykularnych dostosowują powszechne zasady Kodeksu do rzeczywistych potrzeb każdego miejsca. J. LLAQUET, Arciprestazgo, s. 462.
} 
wypełnianie norm i wytycznych, wydane przez arcybiskupa, zarówno generalnie dla całej diecezji, jak i szczególnie dla archiprezbiteratu; bycie instytucją refleksji i oceny sytuacji religijnej dekanatu, w łączności z wikariuszem biskupim, i z głównymi odpowiedzialnymi za duszpasterstwo w diecezji; bycie uprzywilejowaną przestrzenią dla stałej formacji kapłanów i pracowników duszpasterstwa.

Odnośnie do zadań szczegółowych dekanat powinien dążyć do wspierania i programowania okresowych spotkań księży dekanalnych, w celu zdobycia intensywniejszego doświadczenia kapłańskiego braterstwa, wspólnej modlitwy oraz gromadzenia doświadczeń i inicjatyw, które mogą być pomocne w misji duszpasterskiej każdego prezbitera; być miejscem spotkania instytutów życia konsekrowanego, stowarzyszeń, ruchów i zaangażowanych chrześcijan pracujących w parafiach, w celu uzyskania lepszego i bardziej skutecznego włączenia w diecezjalną akcję ewangelizacyjną, w poszanowaniu różnych charyzmatów oraz stworzenia platformy działania, skoordynowanego z planami i potrzebami duszpasterskimi diecezji; kolejnym celem szczegółowym jest proponowanie i realizowanie projektów stałej formacji prezbiterów i laików, zgodnie z tymi promowanymi w diecezji; tworzenie komisji i wyznaczanie odpowiedzialnych w archiprezbiteracie, którzy realizują projekty i działania, przekraczające możliwości pracujących w parafiach, albo wymagają określonej specjalizacji, jak zespoły Caritas, liturgia, katecheza, kursy przedmałżeńskie ${ }^{35}$.

Według Wytycznych dla pracy dekanatu i urzędów dekanalnych Archidiecezji Krakowskiej zasadnicze cele dekanatu można sprowadzić do: koordynacji działań duszpasterskich, przekazywania inspiracji duszpasterskich od urzędów kurialnych do parafii i od parafii do kurii, zapewnienia możliwości twórczej wymiany doświadczeń, dawania okazji do rzeczywistej formacji i duszpastersko-duchowej,

\footnotetext{
${ }^{35}$ Estatutos de los arciprestazgos de la Archidiócesis de Madrid [16 julio 1997] http:// lavozdelcardenal.archimadrid.com/1997/07/16/estatutos-de-los-arciprestazgos-de-la-archidiocesis-de-madrid, [dostęp: 20.11.2015], art. 2, nr 2.
} 
księżom i katechetom ${ }^{36}$. XLII Synod Diecezji Płockiej jako zadania dla dekanatu wymienia: koordynowanie, zespolenie i jednolite prowadzenie działalności duszpasterskiej poszczególnych kapłanów w tej jednostce rozszerzanie i pogłębianie współpracy duszpasterzy, zmierzające do dynamizowania i nadawania większej skuteczności zarówno duszpasterstwu parafialnemu, jak i działaniom o charakterze specjalistycznym i ponadparafialnym ${ }^{37}$.

Estatuto del rciprestazgo y del arcipreste obispado de Palencia potwierdza następujące cele archiprezbiteratu: koordynowanie działań duszpasterskich, popieranie realizacji diecezjalnego projektu duszpasterskiego, wytycznych biskupa i uchwał diecezjalnych, dopasowywanie ich do realiów dekanatu; organizowanie, kiedy jest to pożyteczne, wspólnych działań przewyższających możliwości pojedynczych parafii, takich jak Caritas międzyparafialna, kursy przedmałżeńskie, pielgrzymki do miejscowych sanktuariów, obozy młodzieżowe, promowanie duchowości pracowników duszpasterstwa, szczególnie księży, ich formacji stałej, braterstwa i wzajemnej pomocy między nimi; wspomaganie i wspieranie parafii w procesie ich odnowy duchowej i duszpasterskiej ${ }^{38}$.

Podsumowując można powiedzieć, że zadania dekanatu skupiają się na koordynacji duszpasterstwa, przekazywaniu inspiracji duszpasterskich od urzędów kurialnych do parafii i od parafii do kurii diecezjalnej, zapewnieniu możliwości twórczej wymiany doświadczeń, niesieniu pomocy poszczególnym parafiom $w$ kwestiach przewyższających ich możliwości oraz formacji pracowników duszpasterstwa w dekanacie, szczególnie prezbiterów i diakonów stałych ${ }^{39}$.

\footnotetext{
${ }^{36}$ Wytyczne dla pracy dekanatu i urzędów dekanalnych Archidiecezji Krakowskiej, nr 4, s. 59; por. J. Ostrowski, Dekanat, s. 163.

${ }^{37}$ XLII Synod Diecezji Płockiej (1987-1991), Płockie Wydawnictwo Diecezjalne, Płock 1992, st. 228, s. 113.

${ }^{38}$ Estatuto del rciprestazgo y del arcipreste obispado de Palencia [1 Septiembre 2012], www.diocesispalencia.org [dostęp: 29.12.2015], II, art. 2.

${ }^{39}$ Por. G. Montini, I vicari foranei, s. 377.
} 


\section{Urzędy dekanalne}

Przedstawione wyżej liczne cele dekanatu dla ich owocnego osiągania wymagają zarówno różnych działań, jak i zaangażowania określonych osób. Stąd w przypadku erekcji dekanatów nie tylko jest konieczny urząd dziekana (z prawa powszechnego), ale pożyteczne są także inne funkcje dekanalne, mające charakter administracyjny i duszpasterski (na podstawie prawa partykularnego).

Aktualny Kodeks Prawa Kanonicznego w kan. $553 \$ 1$ stwierdza, że na czele wikariatu rejonowego stoi wikariusz rejonowy, zwany także dziekanem albo archiprezbiterem, który winien być prezbiterem ${ }^{40}$. Mianuje go biskup diecezjalny, po wysłuchaniu zgodnie ze swoim roztropnym osądem zdania kapłanów pełniących posługę w danym dekanacie. Na urząd dziekana, który nie jest związany z urzędem proboszcza określonej parafii, biskup powinien wybrać kapłana, jakiego uzna za odpowiedniego, po rozważeniu okoliczności miejsca i czasu ${ }^{41}$. Funkcja dziekana jawi się obecnie raczej jako pomoc dla proboszczów i innych prezbiterów, niż jako instancja pośrednia między proboszczami i biskupem, czy kurią diecezjalną ${ }^{42}$. Archiprezbiter

\footnotetext{
${ }^{40}$ Gdy Kościół w IV wieku uzyskał wolność i z czasem nastąpiła jego ekspansja na tereny wiejskie oraz zaczął coraz bardziej przenikać życie społeczne, uznał za niezbędne stworzyć figurę dziekana (archiprezbitera), aby kierował parafią macierzystą, albo bardziej eksponowaną, która posiadała chrzcielnicę. Reprezentował on biskupa w określonych celebracjach liturgicznych i gwarantował stabilność organizacyjną w sytuacji sede vacante stolicy biskupiej. W Średniowieczu nabył większe kompetencje: archiprezbiter kierował jako tytulariusz kościołem w mieście, gdzie była siedziba biskupia; do jego zadań należała odpowiedzialność za kościoły chrzcielne na terenach wiejskich; przewodniczył duchownym dekanatu, miał obowiązek odwiedzać i czuwać nad parafiami swojego okręgu, zdając z tego sprawozdanie archidiakonowi i biskupowi i w końcu, uzyskał władzę sądowniczą w trybunale Synodus parochialis. J. Llaquet, Arcipreste, w: Diccionario General de Derecho Canónico, Obra dirigida y coordinada por J. Otaduy, A.Viana, J. Sedano, vol. I, Editorial Aranzadi, Pamplona 2012, s. 463.

${ }^{41}$ Kan. $554 \$ 1$.

${ }^{42}$ J. Sfeir Selim, Le munus regendi dans le Code de Droit Canonique (CIC 83) et le Code des Canons des Églises Orientales (CCEO) de la comparaison à la pastorale, Roma 2001, s. 371.
} 
nie posiada zwyczajnej władzy rządzenia i nie wykonuje jurysdykcji zgodnie z kan. $131 \$ 2$. Jego urząd jest ustanowiony dla koordynacji pasterskiej w imieniu biskupa ${ }^{43}$.

Prawodawca kodeksowy przyjmuje, że oprócz uprawnień prawomocnie mu udzielonych przez prawo partykularne, dziekan ma obowiązek i prawo popierać i koordynować w ramach dekanatu wspólną działalność pasterską; czuwać nad tym, by duchowni jego okręgu prowadzili życie odpowiadające ich stanowi i troskliwie wypełniali swoje obowiązki; czuwać nad tym, by święte czynności były sprawowane zgodnie z przepisami liturgicznymi, by czystość i piękno kościoła i sprzętu liturgicznego, zwłaszcza w sprawowaniu i przechowywaniu Najświętszego Sakramentu były starannie utrzymywane; żeby księgi parafialne były właściwie spisywane i należycie przechowywane, dobra kościelne prawidłowo administrowane, a budynek parafialny otoczony właściwą troską. Dziekan w powierzonym sobie dekanacie zabiega o to, ażeby duchowni zgodnie z postanowieniami prawa partykularnego, uczestniczyli w określonym czasie w prelekcjach, spotkaniach teologicznych lub konferencjach; troszczy się o dostarczenie pomocy duchowych prezbiterom swego okręgu; najbardziej zaś troszczy się o tych kapłanów, którzy znajdują się w trudniejszych okolicznościach lub przeżywają jakieś problemy. Dowiedziawszy się o poważnej chorobie proboszcza w swoim rejonie, dziekan winien zatroszczyć się o to, ażeby nie był on pozbawiony pomocy duchowej i materialnej, a w przypadku śmierci odprawiony był godny pogrzeb. Ma postarać się również o to, aby podczas choroby czy śmierci nie zostały zabrane lub nie zaginęły księgi, dokumenty, sprzęt liturgiczny oraz inne przedmioty należące do kościoła. Dziekan ma obowiązek wizytować parafie swojego rejonu w sposób określony przez biskupa diecezjalnego ${ }^{44}$.

${ }^{43}$ Tamże, s. 373, przypis 419.

${ }^{44}$ Kan. 555; por. AS, nr 218; zob. np. Wytyczne dla pracy dekanatu i urzędów dekanalnych Archidiecezji Krakowskiej, art. 13, s. 61-62; Statut Księży Dziekanów Archidiecezji Lubelskiej, III, s. 715-717; Estatutos de los arciprestazgos de la Archidiócesis de Madrid, art. 7. 
Kodeks Jana Pawła II (podobnie jak poprzedni) nie przewiduje funkcji wicedziekana, jednak powszechnie wprowadziło ją prawo diecezjalne. Tak np. Wytyczne dla pracy dekanatu i urzędów dekanalnych Archidiecezji Krakowskiej zawierają normę, według której wicedziekan należy do zarządu dekanatu ${ }^{45}$. Wspomniany dokument stwierdza, że do szczegółowych zadań wicedziekana należy bycie pierwszym zastępcą dziekana i współodpowiedzialność za zadania powierzone dziekanowi ${ }^{46}$. Statut księży dziekanów Archidiecezji Lubelskiej zaznacza, że najbliższym współpracownikiem dziekana jest wicedziekan, który wspomaga dziekana w wypełnianiu jego urzędu, zastępuje go w przypadku nieobecności lub przeszkody oraz wykonuje zadania zlecone przez dziekana ${ }^{47}$. Identycznie stwierdza Statut księży dziekanów Archidiecezji Częstochowskiej podkreślając, że najbliższym współpracownikiem dziekana jest wicedziekan, który wspomaga dziekana w wypełnianiu jego urzędu, zastępuje go w przypadku nieobecności lub przeszkody oraz wykonuje zadania zlecone przez dziekana ${ }^{48}$. Podobnie stwierdza I Synod Diecezji Legnickiej: „najbliższymi współpracownikami dziekana są wicedziekan i dekanalny ojciec duchowny" ${ }^{49}$. Statuti degli organi di partecipazione diocesani diecezji Concordia-Pordenone mówią, że prowikariusz foranialny (wicedziekan) wspomaga dziekana w jego zadaniach ${ }^{50}$. Directorio arciprestazgo hiszpańskiej diecezji San Cristóbal de La Laguna postanawia, że kiedy biskup uważa za stosowne, może mianować wicearchiprezbitera, aby zastępował archiprezbitera podczas

${ }^{45}$ Wytyczne dla pracy dekanatu i urzędów dekanalnych Archidiecezji Krakowskiej, nr 7-9, s. 61.

${ }^{46}$ Tamże, art. 14. 1, s. 62.

${ }^{47}$ Statut Księży Dziekanów Archidiecezji Lubelskiej [2 grudnia 2000], art. 27, s. 720.

${ }^{48}$ Arcybiskup Metropolita Częstochowski, Statut księży dziekanów Archidiecezji Częstochowskiej, nr 27.

${ }^{49}$ I Synod Diecezji Legnickiej (2007-2012), Statut dziekana, wicedziekana i dekanalnego ojca duchownego w Diecezji Legnickiej, t. I., Legnica 2012, \$1, s. \$25, 134.

${ }^{50}$ Diocesi di Concordia-Pordenone, Statuti degli organi di partecipazione diocesani, SA.GE.PRINT SpA, Pordenone 2006, nr 10, s. 25. 
jego nieobecności i choroby ${ }^{51}$. Na istnienie urzędu wicedziekana wskazuje dekret biskupa portugalskiej diecezji Bragança-Miranda, na mocy którego biskup diecezjalny powołuje kolegium archiprezbiterów i wicearchiprezbiterów na lata 2012-2015 ${ }^{52}$. Według Estatuto del arcipreste en la diócesis de Coria-Caceres w Hiszpanii w każdym archiprezbiteracie ma być także wicearchiprezbiter, który zastępuje archiprezbitera w przypadku jego niezdolności lub nieobecności. Kiedy urząd dziekana wakuje, wicedziekan pełni obowiązki dziekana do czasu wyboru nowego archiprezbitera ${ }^{53}$.

Wicedziekan to kapłan mianowany przez biskupa diecezjalnego. Nie tylko zastępuje on nieobecnego dziekana i wspiera go w jego działalności, ale także niekiedy biskup przyznaje mu na sposób stały jakiś dzieł pracy dziekańskiej ${ }^{54}$.

Prócz urzędu dziekana i wicedziekana dla lepszej działalności dekanatu i koordynacji różnych sektorów działalności pasterskiej foranii, prawo niejednokrotnie przewiduje inne urzędy. Redaktorzy instrukcji Ecclesiae Imago podkreślają, iż w statutach dziekańskich należy szczególnie określić strukturę poszczególnych dekanatów, funkcje w ramach dekanatu, wskazać moderatorów poszczególnych

51 Diócesis de San Cristóbal de La Laguna, Directorio arciprestazgo, www. obispadodetenerife.es/directorio-arciprestazgo-2006/, [dostęp: 12.02.2016], art. 5.

${ }^{52}$ Bispo de BraganÇA-Miranda, Decreto $n^{\circ}$ 16/2012, [14 setembro 2012], www. diocesebm.pt/sites/default/files/documentos/Decreto-16-2012_Col\%C3\%A9gio-dos-Arciprestes.pdf, [dostęp: 13.02.2016].

${ }^{53}$ Estatuto del arcipreste en la diócesis de Coria-Caceres, www.diocesiscoriacaceres. org/menuderecho/Documentos/Estatutos\%20del\%20arcipreste\%20en\%20la\%20 diocesis\%20de\%20Coria-Caceres.pdf, [dostęp: 13.02.2016].

${ }^{54}$ Por. E. Sztafrowski, Prawo kanoniczne w okresie odnowy soborowej. Podręcznik dla duchowieństwa. Tom pierwszy, Warszawa 1976, s. 404. Np. „Wicedziekan prowadzi w ramach dekanatu akcję pomocy dla rodzin wielodzietnych, dla osób samotnych oraz innych potrzebujących. Organizuje wedle możności Dekanalny Dzień Chorych, najlepiej w okresie Wielkiego Postu”. Wytyczne dla pracy dekanatu i urzędów dekanalnych Archidiecezji Krakowskiej, nr IV, 1, s. 63. Do obowiązków wicedziekana należy „opieka nad kapłanami emerytami i chorymi”. Pierwszy Synod Diecezji Rzeszowskiej 2001-2004, Poligrafia Wyższego Seminarium Duchownego w Rzeszowie, Rzeszów 2004, st. 148, s. 94. 
resortów działalności duszpasterskiej. Wskazują przez to, na różne urzędy wikariatu ${ }^{55}$. Także Dyrektorium o pasterskiej posłudze biskupów „Apostolorum Successores mówi o „spotkaniach w obrębie dekanatów odpowiedzialnych za różne sektory duszpasterstwa"56.

Dokładnie tę kwestię reguluje ustawodawstwo partykularne. Prawodawcy formalizują urząd sekretarza dekanatu. Sekretarz dekanatu sporządza sprawozdanie z konferencji dekanalnej, sporządza protokół z objęcia urzędu przez dziekana oraz wykonuje inne prace zlecone przez dziekana. Jest on powoływany przez dziekana ${ }^{57}$.

Według zapisu zawartego w Estatutos del Arciprestazgo de la Diócesis de Cartagena sekretarz archiprezbiteratu jest wybierany przez kondekanalnych niezwłocznie po objęciu urzędu przez archiprezbitera zgodnie z kan. 119 KPK. Jego kadencja trwa trzy lata z możliwością powtórnego wyboru, jednak najwyżej na drugą kadencję. Sekretarzem dekanatu może być jakikolwiek prezbiter, który przebywa i pracuje duszpastersko w obszarze dekanatu. Jego zadaniem jest: sporządzić protokół z każdego zebrania dekanalnego, przesyłać wcześniej do kondekanalnych porządek spotkań dekanalnych, materiały, informacje lub zawiadomienia $z$ odpowiednim wyprzedzeniem do każdego z kapłanów, przechowywać w archiwum cały materiał dotyczący pracy dekanatu. Jego funkcja ustaje po objęciu urzędu przez nowego archiprezbitera ${ }^{58}$.

\footnotetext{
${ }^{55}$ EI, nr 186; zob. E. SzTAFrowsKi, Funkcje dziekana w świetle prawa posoborowego, Kielecki Przegląd Diecezjalny 57(1981) nr 6, s. 270.

${ }^{56}$ AS, nr 218.

${ }^{57}$ Statut Księży Dziekanów Archidiecezji Lubelskiej, art. 29, s. 720-721. Choć prawodawca nie mówi o tym wyraźnie, urząd sekretarza pełni, jak wynika z całości Statutu jeden z prezbiterów dekanalnych.

${ }^{58}$ Estatutos del Arciprestazgo de la Diócesis de Cartagena, www.diocesisdecartagena.org, [dostęp: 20.11.2015], art. 9; por. Arcivescovo Metropolita Campagna, Statuto dei Vicari Foranei [2 dicembre 2014], www.parrocchiagesurisorto.it, [dostęp: 15.11.2015], art. 9; por. Arcidiocesi di AmAlfi-Cava DE' Tirreni, Statuto dei vicari foranei, www.diocesiamalficava.it, [dostęp: 15.11.2015], art. 6; por. IV Synod Archidiecezji Warszawskiej, Wydawnictwo Archidiecezji Warszawskiej, Warszawa 2003 , st. 83 , s. 41 .
} 
Odpowiednikiem sekretarza dekanatu jest notariusz dekanalny. Do jego szczegółowych zadań należy: prowadzenie dokumentacji działania dekanatu i spotkań dekanalnych, księgowość prowadzona na szczeblu dekanatu odnośnie do działalności funduszowo-materialnej, koordynowanie pracy charytatywnej i trzeźwościowej w dekanacie, kontakt z Wydziałem Charytatywnym, Caritasem i referatem trzeźwościowym ${ }^{59}$.

Ważnym urzędem w dekanacie jest funkcja dekanalnego ojca duchownego. Według Statutu Księży Dziekanów Archidiecezji Lubelskiej prezbiter ten jest promotorem doskonałości kapłańskiej w dekanacie. Sam przeto winien odznaczać się wzorową gorliwością kapłańską, a przede wszystkim pogłębionym życiem wewnętrznym, odpowiednim doświadczeniem i autorytetem moralnym wśród kapłanów kondekanalnych. Powołanie odpowiedniego kapłana na urząd ojca duchownego w dekanacie odbywa się na drodze wyborów dokonanych przez kapłanów z dekanatu. Jego wybór podlega zatwierdzeniu przez Arcybiskupa Lubelskiego. Kadencja dekanalnego ojca duchownego trwa 5 lat z możliwością przedłużenia na dalsze pięciolecia. Do głównych zadań ojca duchownego należy troska o rozwój życia wewnętrznego wśród kapłanów dekanatu, ugruntowanie miłości i jedności kapłańskiej oraz jedności kapłanów dekanatu z Arcybiskupem Lubelskim, w szczególny sposób troska o stan duszy kapłana przeżywającego kryzys duchowy. Ojciec duchowny dekanatu wykorzystuje w tym celu wszelkie dostępne sobie formy działania, zawsze jednak w porozumieniu z dziekanem. Organizuje m. in. godziny skupienia podczas konferencji dekanalnych, dekanalne dni skupienia, na których wygłasza konferencje ascetyczne on sam lub zaproszony przez niego kapłan. Służy posługą sakramentu pokuty i w miarę możliwości zapewnia spowiednika spoza dekanatu. W realizowaniu zadań dekanalny ojciec duchowny działa w porozumieniu $\mathrm{z}$ archidiecezjalnym ojcem duchownym, przed którym składa roczne sprawozdanie ze swej działalności oraz omawia z nim plan pracy na

\footnotetext{
${ }^{59}$ Wytyczne dla pracy dekanatu i urzędów dekanalnych Archidiecezji Krakowskiej, nr 15, s. 63; por. E. SzTAfrowski, Ponadparafialni współpracownicy, s. 52.
} 
rok następny ${ }^{60}$. Zgodnie z Wytycznymi dla pracy dekanatu i urzędów dekanalnych Archidiecezji Krakowskiej nieformalny urząd ojca duchownego w dekanacie pełni wicedziekan ${ }^{61}$. IV Synod Archidiecezji Warszawskiej zarządza, że „kapłani dekanatu wybierają spośród siebie ojca duchownego, który czuwa nad liturgicznym i duchowym życiem konfratrów"62.

W dekanacie mogą istnieć urzędy: animatora duszpasterstwa dzieci i młodzieży ${ }^{63}$, animatora duszpasterstwa małżeństw i rodzin, animatora duszpasterstwa chorych, animatora dzieł misyjnych, dyrektora dekanalnej Caritas, dekanalnego korespondenta prasowego (niekoniecznie spośród duchownych) ${ }^{64}$, dekanalnego animatora duszpasterstwa dorosłych ${ }^{65}$.

Z kolei według Statuto dei vicari foranei Archidiecezji Amalfi-Cava de' Tirreni dziekan celem lepszego skoordynowania różnych sektorów duszpasterstwa powoła dekanalne komisje duszpasterskie do spraw: katechezy, caritas, liturgii, powołań, misji, rodziny, młodzieży, szkół, pracy i turystyki, komunikacji społecznej, ekumenizmu, spraw utrzymania duchownych ${ }^{66}$. Choć prawodawca o tym nie wspomina jest jasne, że na czele wymienionych komisji stoją prezbiterzy

${ }^{60}$ Statut Księży Dziekanów Archidiecezji Lubelskiej, art. 30-34, s. 721; por. Pierwszy Synod Diecezji Opolskiej (2002-2005). Statuty i aneksy, Wydawnictwo św. Krzyża, Opole 2005, st. 216, s. 90.

${ }^{61}$ Wytyczne dla pracy dekanatu i urzędów dekanalnych Archidiecezji Krakowskiej, art. 14,2 , s. 62 .

${ }^{62}$ IV Synod Archidiecezji Warszawskiej, st. 83, s. 41; por. W. KraWCzy K, Dziekan we wspólnocie dekanalnej, Studia Płockie 8 (1980), s. 73.

${ }^{63}$ Statut Księży Dziekanów Archidiecezji Lubelskiej, art. 35, s. 721; por. Wytyczne dla pracy dekanatu i urzędów dekanalnych Archidiecezji Krakowskiej, art. 17, s. 63; I Synod Diecezji Legnickiej, Statut dziekana, wicedziekana i dekanalnego ojca duchownego w Diecezji Legnickiej \$26, nr 9, s. 134-135.

${ }^{64}$ Statut Księży Dziekanów Archidiecezji Lubelskiej, art. 35, s. 721; por. I Synod Diecezji Legnickiej, Statut dziekana, wicedziekana i dekanalnego ojca duchownego $w$ Diecezji Legnickiej $\$ 26$, nr 9, s. 134-135.

${ }^{65}$ Wytyczne dla pracy dekanatu i urzędów dekanalnych Archidiecezji Krakowskiej, art. 16, s. 63; por. E. SzTAfrowski, Ponadparafialni współpracownicy, s. 53.

${ }^{66}$ Arcidiocesi di Amalfi-Cava de' Tirreni, Statuto dei vicari foranei, art. 11. 
pełniący urząd przewodniczących. IV Synod Archidiecezji Warszawskiej przypomina, kapłani dekanatu wybierają spośród siebie księży referentów dekanalnych. Zadaniem ich jest pośredniczenie między wydziałami i referatami kurii a duchowieństwem dekanalnym oraz koordynowanie pracy duszpasterskiej w poszczególnych dziedzinach na terenie dekanatu ${ }^{67}$.

\section{Wnioski}

1. Kodyfikacja z 1983 r., mimo, że nie zobowiązuje biskupa diecezjalnego do podziału diecezji na dekanaty, to przejmuje w zasadzie instytucje dekanatów i dziekanów, pozostawiając jednak biskupowi diecezjalnemu swobodę wyboru innych rozwiązań, które wyraźnie proponują różne dokumenty kościelne okresu posoborowego.

2. Instytucja dekanatu, mimo, że jest fakultatywna, została powszechnie przyjęta przez prawo partykularne.

3. Warto, w zależności od potrzeb, tworzyć dekanaty personalne.

4. Ważną kwestią owocnego spełniania swoich zadań przez dekanat jest uwzględnienie kryteriów tworzenia dekanatów sugerowanych przez dokumenty kościelne.

5. Korzystne byłoby ustalenie dla dekanatów wspólnego statutu, zatwierdzonego przez biskupa po konsultacji z Radą kapłańską, w którym winno się określić między innymi jakie urzędy dekanalne winny, czy mogą istnieć w dekanacie w zależności od potrzeb.

6. Należy dowartościować rolę diakonów stałych, osób konsekrowanych i świeckich w wypełnianiu przez dekanat swoich zadań.

7. Tworząc urzędy dekanalne trzeba pamiętać, że piastujący wspomniane urzędy są najpierw współpracownikami dziekana, a dopiero wtórnie referentami wydziałów kurii diecezjalnej.

${ }^{67}$ IV Synod Archidiecezji Warszawskiej, st. 83, s. 41; por. Z. KsıĄżEK, Rola urzędu dziekańskiego w pasterskiej posłudze biskupa, s. 496. 


\section{The vicariate forane and its offices}

The aim of this article is to discuss the institution of the vicariate forane and its offices in the canonical aspect.

The first part focuses on the issues of nomenclature, definition and the establishment of the vicariate forane.

The second part emphasizes the tasks of the vicariate forane, while the third one is devoted to particular positions in the institution of the vicariate forane.

SŁOWA KLUCzowe: dziekan; dekanat; urząd kościelny; prawo partykularne; biskup diecezjalny

KEY WORDS: vicar forane; vicariate forane; ecclesiastical office; particular law; diocesan bishop

\section{Nota o Autorze:}

Ks. DR HAB. JERZY ADAMCZYK - wykładowca prawa kanonicznego w WSD w Radomiu, Jest autorem opracowań z zakresu prawa małżeńskiego, hierarchicznego ustroju Kościoła, sakramentów św. oraz miejsc świętych. 